JIPS, Vol. 2 No. 2

Halaman: 180 - 194

Desember 2021
Jurnal Inovasi Pembelajaran di Sekolah

DOI: 10.51874/jips.v2i2.26

ISSN 2774-9363 (Cetak)

ISSN 2774-9746 (Online)
JIPS

Jurnal Inovasi Pembelajaran di Sekolah

\title{
Supervisi Akademik sebagai Usaha Peningkatan Kinerja Guru dalam Pembelajaran Daring di SDN Kalibanteng Kidul 02 Semarang
}

\author{
Nur Azizah \\ SDN Kalibanteng Kidul 02 \\ aziza18465@gmail.com
}

\begin{abstract}
Many teachers are not able to teach communicatively in learning, as happened in SDN Kalibanteng Kidul 02 Semarang City which on average is less able to teach well in online learning, teachers only give assignments to students without providing further explanation and good guidance ., from 10 teachers there are only 4 teachers who are able to carry out the online learning process using various media, not only by giving assignments to students. The lack of quality of teacher online learning during the pandemic is one of the problems that must be overcome by school principals by carrying out academic supervision. This study is intended to answer the following problems: $1 \mathrm{How}$ is the implementation of academic supervision carried out by school principals to improve teacher performance in online learning at SDN Kalibanteng Kidul 02 Semarang City for the 2020/2021 academic year?. 2) Is there an increase in teacher performance in online learning after academic supervision is carried out at SDN Kalibanteng Kidul 02 Semarang City for the 2020/2021 academic year?. These problems are discussed through classroom action research which is carried out through 2 cycles with each cycle the stages are planning, action, observation and reflection. The results showed that: 1) The implementation of academic supervision carried out by school principals to improve teacher performance in online learning at SDN Kalibanteng Kidul 02 Semarang City for the 2020/2021 academic year was carried out by providing direction and guidance to teachers to be able to utilize and apply web-based learning In the learning that is carried out, the teacher is also given the opportunity to practice the application under the guidance and direction of the researcher and followed by classroom observations to observe the teacher's way of doing online learning. 2) There was an increase in teacher performance in online learning after academic supervision was carried out at SDN Kalibanteng Kidul 02 Semarang City in the 2020/2021 school year, this can be seen from the increase in the results of teacher professionalism in classroom administration management per cycle where in the first cycle there were 19 teachers or $67.9 \%$, and in the second cycle there were 25 teachers or $89.3 \%$. These results indicate that these results are in line with expectations.
\end{abstract}

Keywords: Academic Supervision, Improvement, Teacher Performance, Online Learning

Banyak guru yang kurang mampu mengajar secara komunikatif dalam pembelajran, sebgaimana yang terjadi di SDN Kalibanteng Kidul 02 Kota Semarang yang rata-rata kurang mampu mengajr dengan baik pada pembelajran daring, guru hanya memberikan tugas kepada peserta didik tanpa memberikan penjelasan lebih lanjut dan pembimbingan ssecara baik., dari 10 guru hanya ada guru 4 guru yang mampu melakukan proses pembelajaran darring dengan menggunakan berbagai media, tidak hanya denan memberikan tugas kepada peserta didik. Kurangnya kualitas pembelajaran daring guru di masa pandemi menjadi salah satu masalah yang harus diatasi oleh kepala sekolah dengan dilakukannya supervisi akademik. Studi ini dimaksudkan untuk menjawab permasalahan: 1 Bagaimanakah pelaksanaan supervisi akdemik yang dilakukan oleh kepala sekolah bagi peningkatan kinerja guru dalam pembelajaran daring di SDN Kalibanteng Kidul 02 Kota Semarang tahun pelajaran 2020/2021?. 2) Adakah peningkatan kinerja guru dalam pembelajaran daring setelah dilaksanakan supervisi akdemik di SDN Kalibanteng Kidul 02 Kota Semarang tahun pelajaran 2020/2021?. Permasalahan tersebut di bahas melalui penelitian tindakan kelas yang dilakukan melalui 2 siklus dengan setiap siklus tahapannya adalah perencanaan, tindakan, observasi dan refleksi. Hasil penelitian menunjukkan bahwa: 1) Pelaksanaan supervisi akdemik yang dilakukan oleh kepala sekolah bagi peningkatan kinerja guru dalam pembelajaran daring di SDN Kalibanteng Kidul 02 Kota Semarang tahun pelajaran 2020/2021 dilakukan dengan

Hal. 180 
memberikan pengarahan dan bimbingan kepada guru untuk mampu memanfaatkan dan mengaplikasikan pembelajaran berbasis web dalam pembelajran yagn dilakukan, guru juga diberikan kesempatan untuk mempraktekkan aplikasi tersebut dibawah bimbingan dan arahan peneliti dan dilanjutkan dengan adanya observasi kelas untuk mengamti cara guru dalam melakukan pembelajran daring. 2) Terjadi peningkatan kinerja guru dalam pembelajaran daring setelah dilaksanakan supervisi akdemik di SDN Kalibanteng Kidul 02 Kota Semarang tahun pelajaran 2020/2021, hal ini dapat dilihat dari peningkatan hasil profesionalias guru dalam pengelolaan administrasi kelas per siklus dimana pada siklus I ada 19 guru atau $67.9 \%$, dan pada siklus II sudah mencapai ada 25 guru atau 89.3\%. Hasil tersebut menunjukkan bahwa hasil tersebut sesuai dengan yang diharapkan.

Kata Kunci: Supervisi Akademik, Peningkatan, Kinerja Guru, Pembelajaran Daring

\section{PENDAHULUAN}

Setelah Corona menjadi wabah (pandemik) di Indonesia pada awal bulan Maret 2020 sampai sekarang, pemerintah membuat berbagai macam kebijakan untuk menghadapi serta mengatasi pandemik COVID-19 seperti kebijakan: (1) berdiam diri di rumah (Stay at Home); (2) Pembatasan Sosial (Social Distancing); (3) Pembatasan Fisik (Physical Distancing); (4) Penggunaan Alat Pelindung Diri (Masker); (5) Menjaga Kebersihan Diri (Cuci Tangan); (6) Bekerja dan Belajar di rumah (Work/Study Fom Home) ; (7) Menunda semua kegiatan yang mengumpulkan orang banyak; (8) Pembatasan Sosial Berskala Besar (PSBB); hingga terakhir, (9) pemberlakuan kebijakan New Normal (Tuwu, 2020: 271).

Dampak terbesar dari pandemi COVID-19 yang dirasakan oleh dunia pendidikan di Indonesia adalah adanya kebijakan untuk merubah sistem pembelajaran dari luring menjadi daring. Kebijakan tersebut merupakan implementasi dari Surat Edaran Mendikbud Nomor 3 Tahun 2020 tentang Pencegahan COVID-19 pada Satuan Pendidikan, dan Surat Edaran Nomor 4 Tahun 2020 Tentang Pelaksanaan Kebijakan Pendidikan Dalam Masa Darurat Penyebaran Coronavirus Dease (COVID-19) (Ahmad, 2020: 199).

Bagai guru, pembelajaran Daring banyak sekali hambatan khususnya komunikasi, karena pola pengajaran hanya melalui pesan singkat Whatsapp grup atau geogle clasrom. Bahkan banyak guru yang kurang mampu mengajar secara komunikatif dalam pembelajran, sebgaimana yang terjadi di SDN Kalibanteng Kidul 02 Kota Semarang yang rata-rata kurang mampu mengajr dengan baik pada pembelajran daring, guru hanya memberikan tugas kepada peserta didik tanpa memberikan penjelasan lebih lanjut dan pembimbingan ssecara baik., dari 10 guru hanya ada guru 4 guru yang mampu melakukan proses pembelajaran darring denan menggunakan berbagai media, tidak hanya denan memberikan tugas kepada peserta didik.

Kurangnya kualitas pembelajaran daring guru di masa pandemi menjadi salah satu masalah yang harus diatasi oleh kepala sekolah dengan dilakukannya supervisi akademik. 
Kegiatan yang dilakukan oleh seorang kepala sekolah dalam supervisi yang terkait dengan kegiatan akademik pembelajaran menurut Hartoyo (adalah membantu seorang pendidik mengidentifikasi masalah dan hambatan yang dihadapi terkait dengan tugas dan tanggung jawabnya dalam pembelajaran, kemudian menemukan solusi atas masalah dan hambatan tersebut, sehingga dapat meningkatkan profesionalisme dan kinerja mereka dalam mengelola pembelajaran yang lebih aktif, interaktif, dan efektif (Hartoyo, 2011: 47).

Berdasarkan latar belakang di atas peneliti tertarik untuk mengadakan penelitian tindakan sekolah yang berjudul "Supervisi Akademik Sebagai Usaha Peningkatan Kinerja Guru dalam Pembelajaran Daring di SDN Kalibanteng Kidul 02 Kota Semarang tahun pelajaran 2020/2021"

\section{KAJIAN TEORI}

Supervisi secara etimologi adalah dari kata "super" yang berarti atas dan "visi" yang berarti melihat. Dengan demikian supervisi diartikan melihat dari atas. Berdasarkan pengertian secara etimologi, istilah-istilah supervisi yang dalam praktek, isi dan kegiatannya mengarah pada kegiatan ke-inspeksi, kepengawasan, kepenilik (Imron, 2011: 9).

Istilah supervisi sering ditemukan dalam berbagai kepustakaan baik Indonesia maupun asing, namun istilah supervisi sebenarnya berasal dari kurikulum SD, SMP, SMA yang diartikan pembinaan guru. Jika yang dimaksudkan supervisi adalah pembinaan guru, maka pengertian supervisi secara terminologi sering diartikan sebagai serangkaian usaha bantuan kepada guru terutama bantuan yang berwujud layanan profesional yang dilakukan oleh kepala sekolah, penilik sekolah dan pengawas serta pembina lainnya untuk meningkatkan proses dan hasil belajar (Sahertian dan Mataheru, t.th: 17).

Beberapa definisi di atas secara implisit mengandung ide-ide pokok seperti menggalakkan profesional guru, memberikan layanan dan bantuan kepada guru, dan memecahkan masalah yang berkaitan dengan efektifitas proses belajar mengajar.

Supervisi akademik mengarah pada kualitas input, proses dan akhirnya mempengaruhi kualitas output satuan pendidikan yang bersifat akademik. Mutu output satuan pendidikan dipengaruhi oleh tingkat kesiapan input dan kualitas proses belajar mengajar (Bafadhol, 2002: 241).

Pada hakikatnya, kegiatan supervisi akademik yang dilakukan kepala sekolah adalah berupa pemberian bantuan dan pendampingan (ad vocation) kepada anggotanya: yang dalam hal ini mereka yang terkait dalam aktivitas mengajar guru, peserta didik, staf karyawan, dan 
sebagainya. Ini bertujuan untuk meningkatkan efektifitas dan efisiensi sumber daya sekolah, serta optimalisasi mutu sekolah termasuk didalamnya kualitas kompetensi pedagogik guru.

Tujuan supervisi secara umum adalah memberikan bantuan teknis dan bimbingan kepada guru (dan staf sekolah yang lain) agar personil tersebut mampu meningkatkan kualitas kerjanya, terutama dalam melaksanakan tugas, yaitu melaksanakan proses pembelajaran (Arikunto, 2014: 40).

Jadi supervisi akademik yang baik adalah supervisi pembelajaran yang mampu merefleksi multi tujuan di atas yang meliputi pengawasan kualitas mengajar, pengembangan profesionalitas pendidik dan peningkatan motivasi mengajar pendidik.

Kinerja dalam bahasa Inggris dikenal dengan kata performance yang berarti perbuatan, pekerjaan atau pertunjukan (Poerwadarminta, t.t: 144). Maka kinerja adalah perbuatan seseorang dalam mengemban tugas dan wewenang yang menjadi kewajiban dan tanggung jawabnya yang disertai dengan kemampuan dan keahlian profesi.

Pendidikan Indonesia saat ini dihadapkan kebijakan pembelajaran jarak jauh setelah ada ketetapan oleh Mendikbud guna mengantisipasi penularan Covid-19. Hal tersebut mengacu berdasarkan surat edaran Menteri Pendidikan dan Kebudayaan Nomor 36962/MPK/HK/2020 tentang pembelajaran secara daring dan bekerja dari rumah untuk mencegah penyebaran Covid-19. Konsekuensi dari kebijakan tersebut lembaga pendidikan mengganti pembelajaran luring dengan daring. Dalam surat edaran tersebut juga, Mendikbud menyarankan adanya pemanfaatan teknologi sebagai alat belajar dan mengajar. Pemanfaatan teknologi tersebut dilakukan karena pembelajaran dilakukan secara jarak jauh. Pembelajaran jarak jauh merupakan pembelajaran yang dilakukan tidak bertatap secara langsung antara pengajar dan pembelajar akan tetapi dibantu dengan media untuk melakukan aktivitas proses belajar mengajar (Prawiyogi dkk, 2020).

Kinerja guru dapat dikatakan profesional jika dalam melaksanakan tanggung jawab mendidik, guru memiliki kemampuan dan keahlian khusus dalam melakukan kegiatan di bidang kependidikan untuk memberi ilmu pengetahuan, kecakapan dan ketrampilan kepada si terdidik yang bertujuan untuk mengembangkan seluruh pribadinya.

Ada beberapa kriteria pokok pekerjaan yang bersifat profesional sehubungan dengan profesionalisme seseorang. Nana sudjana memberikan kriteria sebagai berikut; bahwa pekerjaan itu dipersiapkan melalui proses pendidikan dan latihan, mendapat pengakuan dari masyarakat, adanya organisasi profesi, mempunyai kode etik (Sudjana, 2002: 14). 
Indikator kinerja guru menurut Undang-undang No. 14 tahun 2005, tentang Guru dan Dosen (2006:48) meliputi: Penyusunan rencana pembelajaran, pelaksanaan interaksi pembelajaran, penilaian hasil belajar siswa.

Kepala sekolah yang sudah menjalankan peranan-peranannya tentunya akan menuai hasil yang memuaskan, diantaranya meningkatnya kualitas sumber daya manusia, dalam hal ini profesionalisme tenaga ke pendidikan. Dengan bimbingan yang baik terhadap kinerja guru dalam pembelajaran Daring maka peran kepala sekolah sebagai supervisor akademik akan dapat memberikan peningkatan kinerja guru dalam pembelajaran Daring. Lebih jelasnya peneliti gambarkan dalam bagan berikut: 


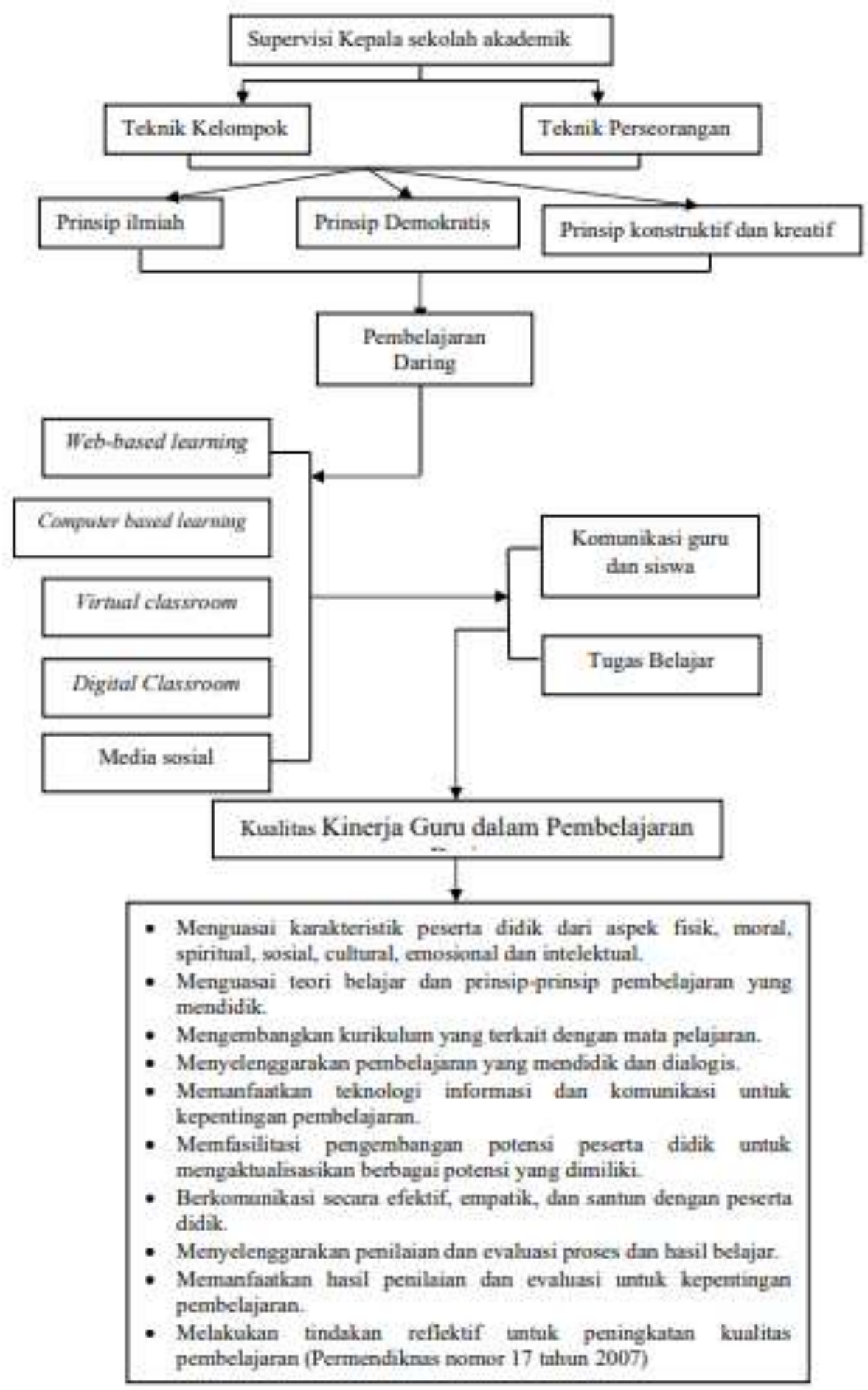

Gambar 1. Kerangka Berpikir

Hipotesis tindakan dalam penelitian ini adalah pelaksanaan supervisi akdemik yang dilakukan oleh kepala sekolah dapat meningkatkan kinerja guru dalam pembelajaran daring di SDN Kalibanteng Kidul 02 Kota Semarang tahun pelajaran 2020/2021.

\section{METODE PENELITIAN}

Hal. 185 
Jenis penelitian kelas ini adalah penelitian tindakan (action research). menurut Reason dan Bardbury yang dikutip oleh Ernie Stringer menyatakan action research as " $a$ participatory, democratic process concerned with developing practical knowing in the pursuit of worthwhile human process, grounded in a participatory worldview which we believe is emerging at this historical moment. It seeks to bring together action and reflection, theory and practice, in participation with others, in the pursuit of practical solutions to issues of pressing concern to people, and more generally the flourishing of individual persons and their communities (Stringer, 2008: 10). (Penelitian tindakan sebagai sebuah proses demokrasi partisipatif yang bersangkutan dengan pengetahuan pengembangan praktis dalam mengejar proses manusia yang berharga, didasarkan pada pandangan dunia partisipatif yang kami percaya merupakan sejarah yang muncul pada saat ini. Ia berusaha untuk menyatukan aksi dan refleksi, teori dan praktek, partisipasi dengan orang lain, dalam mengejar solusi praktis untuk masalah menekan perhatian orang, dan lebih umum maraknya orang-orang individu dan komunitas). Dalam penelitian ini peneliti tindakan yang digunakan adalah penelitian tindakan sekolah (PTS).

Tempat penelitian SDN Kalibanteng Kidul 02 Kota Semarang. Penelitian ini dilakukan pada tanggal 18 januari 2021 sampai 30 Maret 2021. Adapun subjek dalam penelitian ini adalah seluruh guru SDN Kalibanteng Kidul 02 Kota Semarang tahun pelajaran 2020/2021 sejumlah 10 guru. Variabel penelitian terdiri atas variabel bebas dan variabel terikat. Variabel bebas (yang mempengaruhi) dalam penelitian ini adalah supervisi akdemik yang dilakukan oleh kepala sekolah sedangkan variabel terikatnya (yang dipengaruhi) adalah kinerja guru dalam pembelajaran daring. Dalam penelitian tindakan sekolah ini yang melaksanakan tindakan adalah peneliti dan guru SDN Kalibanteng Kidul 02 Kota Semarang tahun pelajaran 2020/2021.

Kolaborator adalah suatu kerja sama dengan pihak-pihak terkait seperti atasan, sejawat, atau kolega. Kolaborator ini di harapkan dapat di jadikan sumber data, karena pada hakekatnya kedudukan peneliti pada penelitian tindakan sekolah ini merupakan bagian dari situasi dan kondisi dari suatu latar yang ditelitinya. Peneliti tidak hanya sebagai pengamat, tetapi juga terlibat langsung dalam proses situasi dan kondisi (Departemen Pendidikan Direktorat, 2003: 13). Kerjasama ini diharapkan dapat memberikan informasi dan kontribusi yang baik sehingga dapat tercapai tujuan dari penelitian ini. Yang menjadi kolaborator disini adalah guru senior sebagai kolaborator. 
Penelitian tindakan sekolah ini menggunakan Penelitian tindakan kelas ini dipilih dengan menggunakan model spiral dari John Elliot yaitu seperti dikemukakan berikut ini (Subyantoro,2009: 9-10).

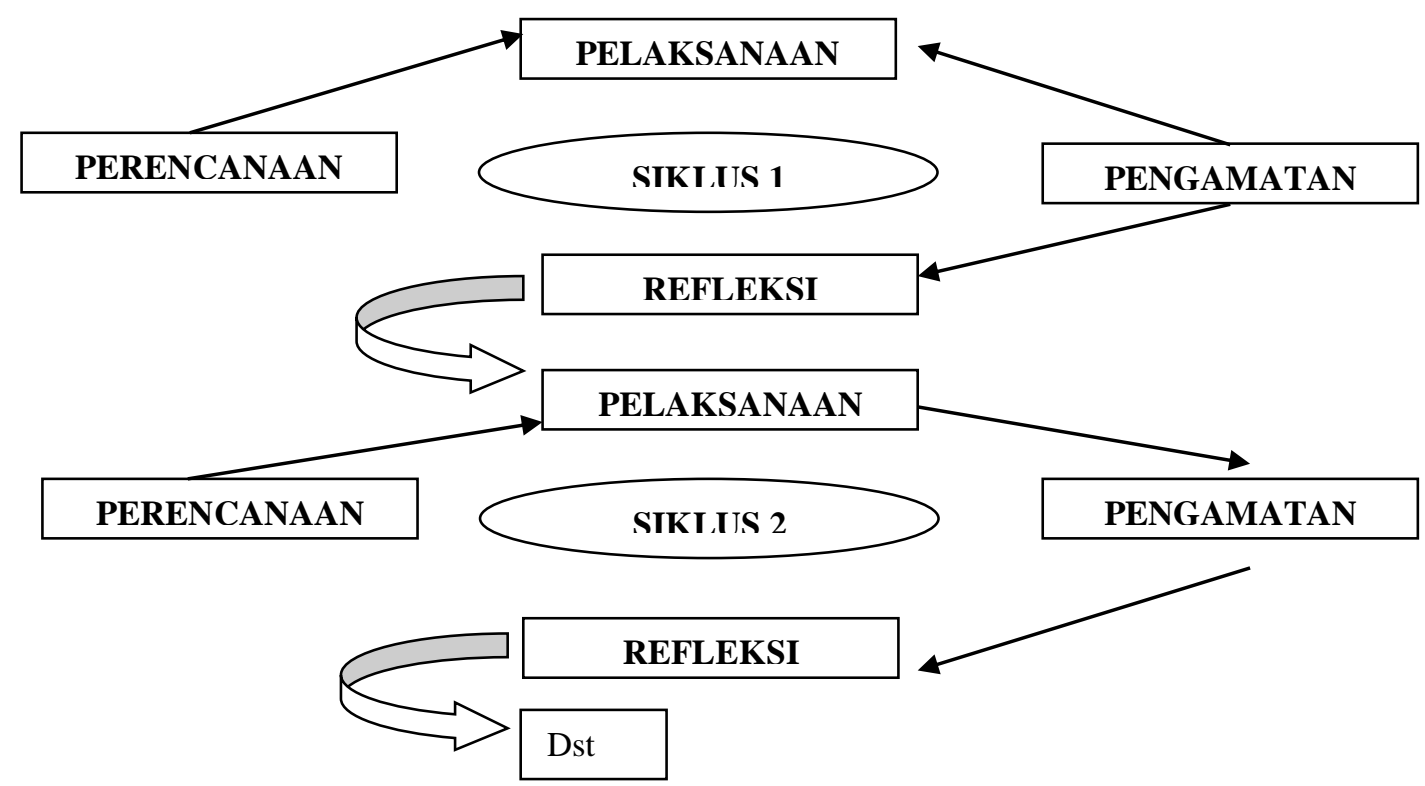

Gambar 2. Desain Penelitian Model John Elliot

Alat penilaian yang digunakan peneliti adalah lembar penilaian kemampuan mengajar yang dilakukan guru.

1. Analisis deskriptif kualitatif

Analisis deskriptif kualitatif, artinya seluruh data yang terkumpul diolah secara non statistik untuk menggambarkan situasi hasil penelitian. Analisis ini digunakan untuk mengetahui aktivitas peserta didik selama proses pembelajaran (Sugiono, 2007: 335).

2. Analisis kuantitatif

Analisis kuantitatif dilakukan untuk mengolah data dari hasil tes peserta didik setiap siklusnya. Analisa data yang bersifat deskriptif kuantitatif dengan analisis persentase dan analisa rata-rata. Data kuantitatif ini diolah berdasarkan data hasil pengamatan melalui pengamatan kinerja guru dalam pembelajran daring menggunakan lembar penilaian (Sugiono, 2007: 335). Untuk mengukur persentase keberhasilan guru secara individu menggunakan rumus :

$$
\text { Nilai }=\frac{\text { Skor yang dicapai }}{\text { skor maksimal }} \times 100 \%
$$

Sedangkan untuk mengetahui keberhasilan klasikal atau keseluruhan guru digunakan rumus berikut :

$$
\mathrm{P}=\frac{\sum n 1}{\sum n 2} x 100 \%
$$


Keterangan :

$\mathrm{P}$

: Nilai keberhasilan

$\sum n 1 \quad$ : Jumlah guru yang berhasil

$\sum n 2 \quad:$ Jumlah total guru

Sedangkan Untuk mengetahui tingkat keberhasilan penelitian tindakan sekolah ini apabila terjadi peningkatan kinerja guru dalam pembelajaran daring pada kategori baik dan baik sekali sebanyak $85 \%$.

Kriteria:

Baik Sekali (A): $90<\mathrm{A} \leq 100$

Baik (B) $\quad: 70<\mathrm{B} \leq 89$

Cukup (C) $\quad: 50<\mathrm{C} \leq 69$

Kurang $(\mathrm{K}) \quad: \leq 49$

\section{HASIL PENELITIAN}

Siklus I

Pelaksanaan siklus I dilakukan pada tanggal 18 Januari 2021. Berdasarkan supervisi akademik yang dilalukan peneliti terhadap kinerja guru dalam pembelajaran daring diperoleh hasil penilaian kinerja guru. Untuk lebih jelasnya diperoleh data yang digambarkan dalam tabel dan diagram berikut:

Tabel 1. Kinerja Guru dalam Pembelajaran Daring Siklus I

\begin{tabular}{|c|c|c|c|}
\hline \multirow{2}{*}{ Kategori } & \multirow{2}{*}{ Angka } & \multicolumn{2}{c|}{ Siklus I } \\
\cline { 3 - 4 } & & guru & $\%$ \\
\hline Baik Sekali & $90 \%-100 \%$ & 2 & $25 \%$ \\
Baik & $70 \%-89 \%$ & 4 & $50 \%$ \\
\hline Cukup & $50 \%-69 \%$ & 2 & $25 \%$ \\
Kurang & $<49 \%$ & 0 & $0 \%$ \\
\hline \multicolumn{2}{|c|}{ Jumlah } & 8 & $100 \%$ \\
\hline
\end{tabular}

Dari tabel di atas dapat diketahui kinerja guru dalam pembelajaran daring pada siklus I dimana pada kategori baik sekali sebanyak 2 guru atau 25\%, kategori baik sebanyak 4 guru atau 50\%, kategori cukup sebanyak 2 guru atau 25\%, kategori kurang sebanyak 0 guru atau $0 \%$. 
Dari tabel di atas menunjukkan Kinerja Guru dalam Pembelajaran Daring kurang baik dan perlu ada peningkatan tindakan dalam supervisi manajerial yang dilakukan peneliti pada siklus berikutnya

\section{Siklus II}

Pelaksanaan siklus II dilakukan pada tanggal 9 Februari 2021. Berdasarkan supervisi akademik yang dilalukan peneliti terhadap kinerja guru dalam pembelajaran daring diperoleh hasil penilaian kinerja guru. Untuk lebih jelasnya diperoleh data yang digambarkan dalam tabel dan diagram berikut:

Tabel 2. Kinerja Guru dalam Pembelajaran Daring Siklus II

\begin{tabular}{|c|c|c|c|}
\hline \multirow{2}{*}{ Kategori } & \multirow{2}{*}{ Angka } & \multicolumn{2}{c|}{ Siklus I } \\
\cline { 3 - 4 } & & guru & $\%$ \\
\hline Baik Sekali & $90 \%-100 \%$ & 4 & $50 \%$ \\
Baik & $70 \%-89 \%$ & 3 & $38 \%$ \\
\hline Cukup & $50 \%-69 \%$ & 1 & $13 \%$ \\
Kurang & $<49 \%$ & 0 & $0 \%$ \\
\hline \multicolumn{2}{|c|}{ Jumlah } & 8 & $100 \%$ \\
\hline
\end{tabular}

Dari tabel di atas dapat diketahui kinerja guru dalam pembelajaran daring pada siklus I dimana pada kategori baik sekali sebanyak 2 guru atau 25\% meningkat dari siklus I yaitu 4 guru atau 50\%, kategori baik sebanyak 4 guru atau 50\% meningkat dari siklus I yaitu 3 guru atau 38\%, kategori cukup sebanyak 2 guru atau 50\% meningkat dari siklus I yaitu 1 guru atau $13 \%$, kategori kurang sama dengan siklus I.

\section{PEMBAHASAN}

Berdasarkan hasil penelitian secara keseluruhan terjadi peningkatan kinerja guru dalam pembelajaran daring setelah dilaksanakan supervisi akdemik di SDN Kalibanteng Kidul 02 Kota Semarang tahun pelajaran 2020/2021 diakhir tindakan siklus II. Maka dari hasil analisis dapat diketahui data terjadi peningkatan kinerja guru dalam pembelajaran daring setelah dilaksanakan supervisi akdemik di SDN Kalibanteng Kidul 02 Kota Semarang tahun pelajaran 2020/2021. 
Kinerja guru dalam pembelajaran daring setelah dilaksanakan supervisi akdemik di SDN Kalibanteng Kidul 02 Kota Semarang tahun pelajaran 2020/2021, terjadi peningkatan per siklusnya, untuk lebih jelasnya dapat di lihat dalam tabel dan grafik berikut:

Tabel 3. Perbandingan Kategori Kinerja Guru dalam Pembelajaran Daring Siklus I dan Siklus II

\begin{tabular}{|c|c|c|c|c|c|}
\hline \multirow{2}{*}{ Kategori } & \multirow{2}{*}{ Nilai } & \multicolumn{2}{c|}{ Siklus I } & \multicolumn{2}{c|}{ Siklus II } \\
\cline { 3 - 6 } & & Guru & Prosentase & Guru & Prosentase \\
\hline Baik Sekali & $90 \%-100 \%$ & 2 & $25 \%$ & 4 & $50 \%$ \\
\hline Baik & $70 \%-89 \%$ & 4 & $50 \%$ & 3 & $38 \%$ \\
\hline Cukup & $50 \%-69 \%$ & 2 & $25 \%$ & 1 & $13 \%$ \\
\hline Kurang & $<49 \%$ & 0 & $0 \%$ & 0 & $0 \%$ \\
\hline \multicolumn{2}{|c|}{ Jumlah } & 8 & $100 \%$ & 8 & $100 \%$ \\
\hline
\end{tabular}

Berdasarkan tabel dan grafik di atas menunjukkan kinerja guru dalam pembelajaran daring pada siklus I ada 6 guru atau $75 \%$ dan pada siklus II ada 7 guru atau $88 \%$, hasil tersebut sudah mencapai indikator yang ditentukan yaitu terjadi peningkatan kinerja guru dalam pembelajaran daring setelah dilaksanakan supervisi akdemik di SDN Kalibanteng Kidul 02 Kota Semarang tahun pelajaran 2020/2021 pada siklus I, siklus II tiap individu yang mencapai $85 \%$ dari seluruh jumlah guru. Berdasarkan hasil penelitian yang telah dikemukakan di atas, pada pelaksanaan tindakan siklus I dan siklus II dapat diketahui perubahan-perubahan hasil peningkatan kinerja guru dalam pembelajaran daring setelah dilaksanakan supervisi akdemik di SDN Kalibanteng Kidul 02 Kota Semarang tahun pelajaran 2020/2021.

Dari hasil di atas dapat peneliti analsisi bahawa kinerja kepala sekolah sebagai supervisor akademik menuntut kemampuan kepala sekolah dalam melakukan pengawasan dan pengendalian untuk meningkatkan kualitas tenaga kependidikan khsusunya dalam pembelajaran daring. Kegiatan supervisi dilakukan supervisor melalui teknik individu dan teknik kelompok.

\section{SIMPULAN}

Hal. 190 
Dari hasil penelitian dan pembahasan dapat diambil kesimpulan sebagai berikut :

1. Pelaksanaan supervisi akdemik yang dilakukan oleh kepala sekolah bagi peningkatan kinerja guru dalam pembelajaran daring di SDN Kalibanteng Kidul 02 Kota Semarang tahun pelajaran 2020/2021.

2. Terjadi peningkatan kinerja guru dalam pembelajaran daring setelah dilaksanakan supervisi akdemik di SDN Kalibanteng Kidul 02 Kota Semarang tahun pelajaran 2020/2021

\section{SARAN}

Berdasarkan hasil peneliti, maka ini peneliti mengajukan beberapa saran:

1. Pelaksanaan supervisi akademik perlu menajdi salah satu agenda penting dan rutin yang harus dilakukan oleh kepala sekolah dan agar dapat dilakukan tidak hanya sampai pada selesainya penelitian ini saja.

2. Perlunya pendekatan secara personal oleh kepala sekolah terhadap para guru.

3. Kepada para guru, sudah seharusnya meningkatkan peningkatan kinerja guru dalam pembelajaran daring.

\section{DAFTAR PUSTAKA}

Abidah, A., dkk. , 2020, The Impact of Covid-19 to Indonesian Education and Its Relation to the Philosophy of "Merdeka Belajar." Studies in Philosophy of Science and Education SiPoSE, Vol. 1 No. 1

Ahmad, Iqbal Faza, 2020, Alternative Assessment In Distance Learning In Emergencies Spread Of Coronavirus Disease Covid-19 In Indonesia, Jurnal Pedagogik, Vol. 07 No. 01, Januari-Juni

Ali, Mudzakkir, 2012, Ilmu Pendidikan Islam, Semarang: PKPI2 Universitas Wahid Hasyim

Amstrong, David G. dan Tom V. Savage, 1983, Secondary Education an Introduction, New York: Macmillan Publissing Co. Inc.

Arikunto, Suharsimi, 2013, Organisasi Administrasi Pendidikan Teknologi dan Kejuruan, Jakarta: PT. Raja Grafindo Persada,

-----------, 2014, Dasar-Dasar Supervisi, Jakarta: Rineka Cipta

Bafadhol, Ibrahim, 2002, Supervisi Pembelajaran Teori dan Aplikasinya dalam Membina Profesionalitas Pendidik, Jakarta: Bumi Aksara

Best, John, W, 1981, Research in Education, United State of America: Prentice-Hall., Inc 
Bondi, John wiles Joseph, t.th, Supervision A Guide To Practice, Charles E Morril Publising Company

Daryanto, 2011, Administrasi Pendidikan, Jakarta: PT. Rineka Cipta

Denny, Richard, 1992, Sukses Memotivasi, Jakarta: PT. Gramedia

Departemen Agama RI, 2013, Pedoman Pengembangan Administrasi dan Supervisi Pendidika,n Jakarta

Departemen Pendidikan Direktorat Jendral Pendidikan Dasar dan Menengah, 2003, Penelitian Tindakan Kelas, Direktorat Tenaga Kependidikan

Hartoyo, 2011, Supervisi Pendidikan Menuju Sekolah Efektif dalam Kerangka Manajemen Berbasis Sekolah, Semarang: Pelita Insani

Herliandry, L. D., dkk., 2020, Pembelajaran Pada Masa Pandemi Covid-19. Jurnal Teknologi Pendidikan, Volume 22 No. 1

http://hafismuaddab.wordpress.com/2011/03/23/ciri-ciri-supervisi-yang-efektif,

https://edukasi.sindonews.com

Imron, Ali, 2011, Pembinaan Guru di Indonesia, Yogyakarta: Pustaka Pelajar

Indrafachrudi, Soekarto, 2013, Mengantar Bagaimana Memimpin Sekolah Yang Baik, Jakarta: Ghia Indonesia

Lindgren, Henry Clay, 1960, Educational Psychology In The Classroom, Tokyo-Japan: Modern asia

Mangkunegara, Anwar Prabu, 2004, Manajemen Sumber Daya Manusia, Bandung: Rosda Karya

Maries, Ben, t.th, Supervision Behavior in Education Prentice Hall, n. Englandood Chaliffs, New Jersey

Morgan, Clifford T., 1971, Introduction to Psychology, Sixth Edition, New York: MC Graw Hill International Book Company

Mulyasa, 2007, "Standar Kompetensi dan Sertifikasi Pendidik”, Bandung: Remaja Rosdakarya

-----------, Manajemen Berbasis Sekolah, Bandung: Remaja Rosdakarya, 2013

Nasrullah, Rulli, 2015, Media Sosial: Perspektif Komunikasi, Budaya, dan Sosioteknologi. Bandung: Simbiosa Rekatama Media

Nasution, S., 2014, Kurikulum dan Pengajaran, Jakarta: Bina Aksara

Nawawi, H. Hadari, 1985, Organisasi Sekolah Dan Pengelolaan Kelas Sebagai Lembaga Pendidikan, Jakarta; Gunung Agung

Hal. 192 
Novianti1, Ely, Alda Rizka Fatkhia dan Zalik Nuryana, 2020, Analisis Kebijakan Pembelajaran PAI Di Masa Pandemi: Peluang Dan Tantangan, Jurnal Pendidikan Islam Volume 11, Nomor 2, November

Nurdin, Syafruddin, dan Basyiruddin Usman, 2003, Guru Profesional dan Implementasi Kurikulum, Jakarta: Ciputat Press

Nuryana, Z., 2019, Pemanfaatan Teknologi Informasi dalam Pendidikan Agama Islam. TAMADDUN Jurnal Pendidikan Dan Pemikiran Keagamaan, volume 19 No 1

Oke, A.and F. A. P. Fernandes, 2020, Innovations in Teaching and Learning: Exploring the Perceptions of the Education Sector on the 4th Industrial Revolution 4IR , Journal of Open Innovation: Technology, Market, and Complexity, volume 6 No. 31

Pidarte, Made, 2010, Peranan Sekolah Pada Pendidikan Dasar, Jakarta: PT. Grasindo

Pitasari, E. P., eds, 2014, Panduan untuk Optimalisasi Media Sosial untuk Kementrian Perdagangan RI, Jakarta Pusat: Kementrian Perdagangan

Poerwadarminta, W.J.S, t.t, Kamus Lengkap: Inggris -Indonesia, Indonesia Inggris, Bandung: Hasta,

Prawiyogi, Anggy Giri dkk., 2020, Efektivitas Pembelajaran Jarak Jauh Terhadap Pembelajaran Siswa di SDIT Cendekia Purwakarta, Jurnal Pendidikan Dasar, Volume 11 Nomor 1

Purwanto, Ngalim, 2010, Administrasi Pendidikan Jakarta : Mutiara

Ritonga, A.W., dkk., 2020, E-Learning Process of Maharah Qira'ah in Higher Education during the Covid-19 Pandemic. International Journal of Higher Education, volume 9

Rusman dkk., 2011, Pembelajaran Berbasis Teknologi Informasi Dan Komunikasi: Mengembangkan Profesionalitas Guru, Jakarta: Raja Grafindo Persada

Sahertian, Piet A. dan Frans Mataheru, t.th, Prinsip dan Teknik Supervisi Pendidikan, Surabaya: Usaha Nasional

-----------, 2010, Konsep Dasar dan Teknik Supervisi Pendidikan Dalam Rangka Pengembangan Sumber Daya Manusia Jakarta : Rineka Cipta

Sardiman, 2001, Interaksi dan Motivasi Pembelajaran, Jakarta: Raja Grafindo Persada

Slamet PH, 2012, Kepemimpinan Kepala Sekolah, Makalah dan Lokakarya Nasional

Stringer, Ernie, 2008, Action Research in Education, New Jersey: Library Congress

Subari, 2010, Supervisi Pendidikan Dalam Rangka Perbaikan Situasi Mengajar, Jakarta: Bumi Aksara

Subyantoro,2009, Penelitian Tindakan Sekolah, Semarang: CV. Widya Karya

Hal. 193 
Sudjana, Nana, 2002, Dasar-Dasar Proses Belajar Mengajar, Bandung: Sinar Baru Algesindo

Sugiono, 2007, Metodelogi Penelitian Pendidikan Pendekatan Kuantitatif, Kualitatif dan $R \& D$ Bandung : Alfabeta

Suryani, N., 2016, Utilization of Digital Media to Improve The Quality and Attractiveness of The Teaching of History. Proceeding The $2^{\text {nd }}$ International Conference On Teacher Training and Education Sebelas Maret University, 2

Suryosubroto, 2007, Proses Pembelajaran di Sekolah, Jakarta: Rineka Cipta , 2014, Manajemen Pendidikan di Sekolah, Jakarta: Rineka Cipta

Susilo, dkk. 2020. Coronavirus Disease 2019: Tinjauan Literatur Terkini, Jurnal Penyakit Dalam Indonesia, Vol. 7

Sutopo, Hendiyat dan Wasty Sumanto, t.th, Kepemimpinan dan Supervisi Pendidikan, Jakarta: PT. Bina Aksara

Tiffin, I dan Mc. Cormick, E.S, 1965, Industry Psychology, New Jersey: Prentice Hall Inc. Englewood Cliffs Homewood Linolis

Tuwu, Darmin. 2020, Kebijakan Pemerintah dalam Penanganan Pandemi COVID-19, Journal Publicuho Volume 3. No. 2

Umiarso dan Imam Gojali, 2010, Manajemen Mutu Sekolah di Era otonomi Pendidikan ("Menjual" Mutu Pendidikan Dengan Pendekatan Quality Control bagi Pelaku Lembaga Pendidikan, Jogjakarta: IRCiSod

Undang - Undang Republik Indonesia Nomor 14 Tahun 2005 tentang Guru dan Dosen.

Wahyosumidjo, 2001, Kepemimpinan Kepala Sekolah Tinjauan Teoritik dan Permasalahannya, Jakarta: Raja Grafindo Persada

Winarno dan R. Eko Djuniarto, 2003, Perencanaan Pembelajaran, Jakarta: Direktorat Tenaga Kependidikan

Witting, Arno F., t.th., Theory and Problems of Psychology of Learning, New York: Mc Graw Hiil Book Company

Zarella, D., 2010, The Social Media Marketing Book, Canada: O’Reilly Media

Zuhairini, dkk., 1993, Metodologi Pendidikan Agama, Solo: Ramadhani

Hal. 194 